much more powerful influence of the mental state on the form sense than on the light sense; and with the -important fact that the minimum light sense is practically never outside normal limits except in established organic disease.

I regret that $\$$ have found it necessary to be critical over such painstaking investigation but the problem will remain tangled and pre-judged if surmise and peradventure continue to

"drag at each remove a lengthening chain."

Yours faithfully,

I. C. Michaelson,

January 4, 1945.

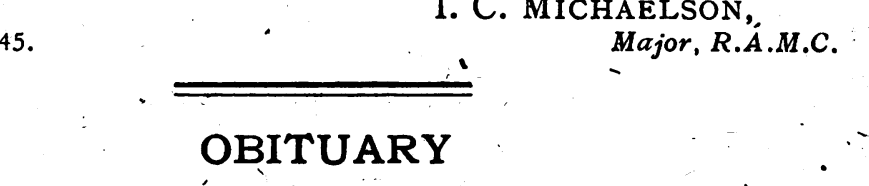

\title{
THOMAS HARRISON BUTLER
}

By the death of Thomas Harrison Butler on January 29, British, Ophthalmology has lost one of its outstanding personalities. The son of a clergyman, he was born in 1871. His early education was received at Dorchester Grammar School and St. Paul's School. Proceeding to Corpus Christi College, Oxford, he obtained first class honours in Natural Sciences. His clinical course was taken at St. Bartholomew's Hospital and from there he qualified B.M. in 1895.

After holding a number of resident hospital appointments; a, Radcliffe Travelling Fellowship enabled him to widen his experience by study on the Continent for several years - during which time he worked at Paris, Berlin and-Vienna and other centres. Later he practised for several years in South Africa and on returning to this country he obtained his doctorate of medicine in 1902. For 4 years. he was Assistant Surgeon to the British Ophthalmic Hospital at Jerusalem, where he gained valuable experience in eye diseases, which laid the foundation of his future career.

On his return to England, he commenced practice as an Ophthalmologist at Leamington and Coventry, and became Honorary Ophthalmic Surgeon to the, Coventry and Warwickshire Hospital and to the Warneford Hospital, Leamington. In 1913 he was appointed a member of the honorary staff of the Birmingham and Midland Eye Hospital. Retiring-from this position in 1932, he returned to assist the depleted staff when his son-who was Assistant Surgeon to the Hospital-was called to the Forces at the outbreak of war:

He wrote much and was a frequent contributor to the Medical. Journals. An authority on the slit-lamp, his book: "An Illustrated Guide to the Slit-lamp,"' was the first printed in English on this subject. It is interesting to note that practically all the illustrations in this book were reproduced from his own drawings-for he possessed considerable skill as an artist. 
He was a familiar figure at most of the society meetings and during his long career he came to hold with distinction many high offices. At different times he was President of the Ophthalmological Society of the United Kingdom, of the Ophthalmic Section of the British Medical Association and of the Midland Ophthalmological Society. The last named society was especially indebted to him, for not only was he president for three years but was honorary secretary for nearly 30 years. 'For many years he was a member of the Council of the Oxford Ophthalmological Congress and contributed much to its success. He delivered the Doyne Memorial lecture and received the Doyne medal in 1924 and was Middlemore lecturer in 1915, 1922 and 1930.

As evidence of his outstanding merit and of the esteem in which he was held by his colleagues, he was elected an Honorary Fellow of the Royal College of Surgeons in 1941-a rare but well deserved honour.

- A man of unbounded energy and enthusiasm, he succeeded in infusing others with these qualities. $\mathrm{He}$ was always ready to help and advise his House Surgeons and juniors, and many of us, both in this country and in the colonies, owe him a debt of gratitude. He derived the greatest satisfaction from his'work, gave of his best to it and was always anxious to share his knowledge and experience with others. Patients were not merely cases to him but individuals in whom he took a deep intèrest, who could look to him for. help and advice.

Even in his later years, he retained a youthful outlook and any new departure in treatment or new technique in operating claimed his attention and interest.

To interests outside his profession he brought the same wholehearted enthusiasm. He was a well-known yachtsman and a keen member of the Royal Cruising Club. Last year he was President of the Little Ship Club. In the little leisure he had, he achieved a. wide reputation as a designer of small cruising yachts and has recently written a book on the subject.

His genial and kindly personality endeared him to all with whom he came in contact. He will be greatly missed, not only in his own immediate circle, but wherever ophthalmologists meet, and those who knew him well will feel a sense of personal loss-the loss of a great colleague and friend. Our sincere sympathy is extended to his widow and family:

\section{Dr: F. A. Anderson writes :-}

C. $\mathrm{R}$.

It is difficult to realise that Harrison Butler has left us and that we shall not again see, that benign figure, at our meetings, for no ophthalmological gathering seemed quite complete without him. He was an undoubted personality and he brought an air of bonhomie to an assembly which had a quality all its own. In this respect he 


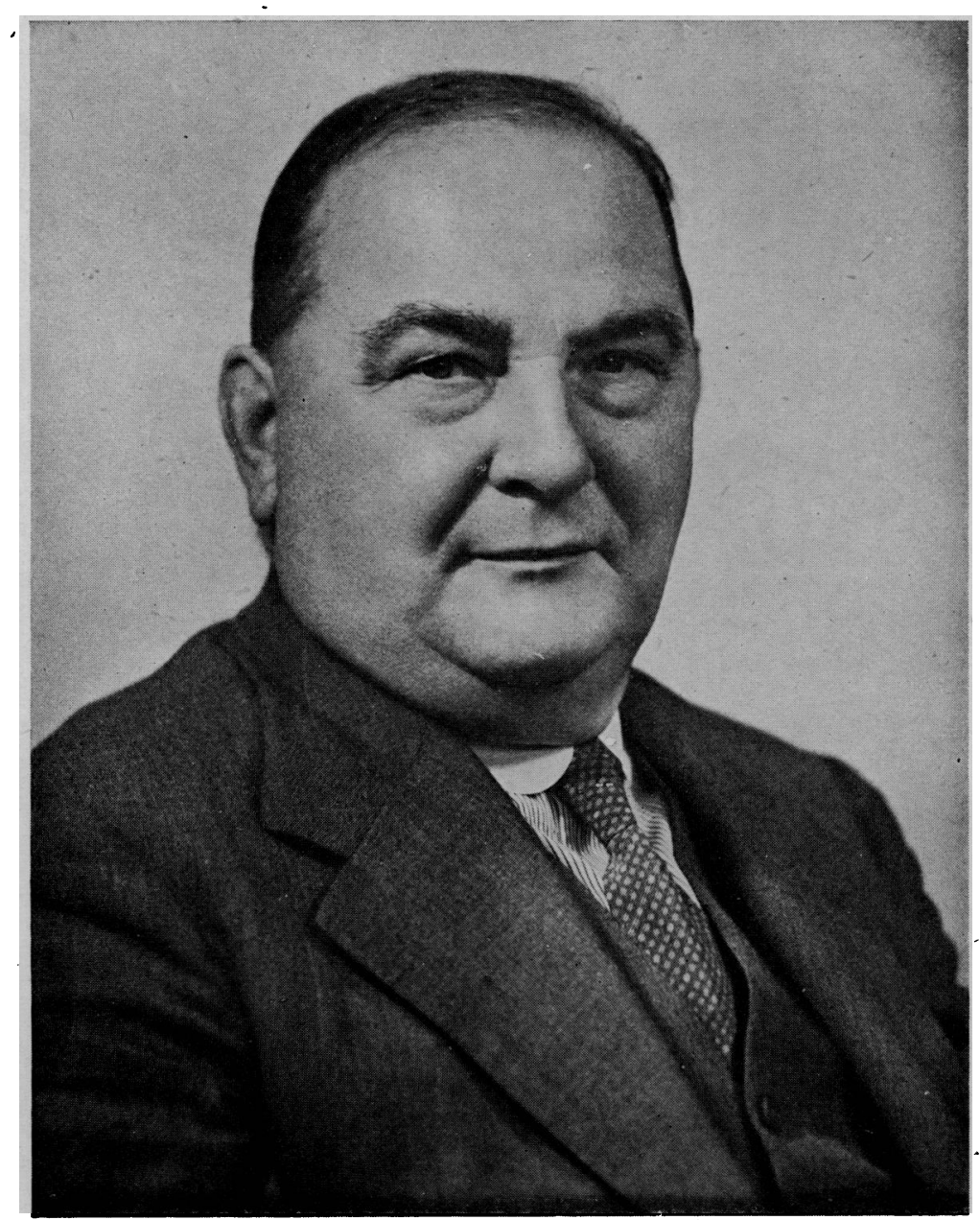

Photo by H. J .Whitlock \& Sons L:d., Birmin, ${ }_{\text {Sh.lm }}$

THOMAS HARRISON BUTLER 


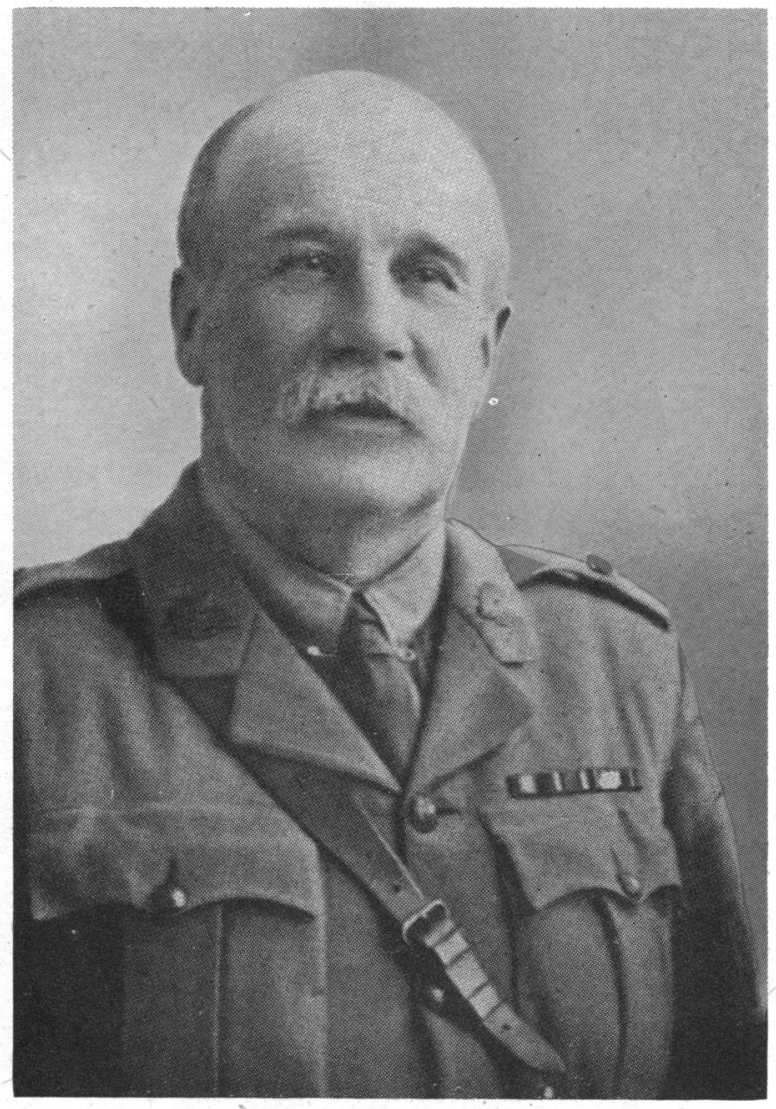

JOHN LOCKHART GIBSON 
changed very little in the last thirty years. His humour had a certain Churchillian quality and like that great man he was great enough and honest enough to be able to make a joke at his own expense or to confess to some minor fault in technique which frequently untied the tongues of more reticent members to the great advantage of the meeting. His contributions to debate always had the flavour of originality, coupled with much wisdom, learning, and common sense, while his wide experience and keen observation enabled him to shed light on any subject. Many of us owe a debt of gratitude to Butler for his "Illustrated Guide to the Slit-lamp" which was the first original book on the subject in English. It was characteristic of him that he always referred to his book as the "Child's Guide to Knowledge," thus refusing to accept a pedestal to which it might well have entitled him.

Butler was perhaps seen at his best at the Oxford Congress which he served with,great devotion and enthusiasm from its inception. He read the Doyne Memorial Lecture in 1924. As a member of the Council since 1917 he seldom missed a. Meeting and his contributions to the deliberations of that body were largely-responsible for the success of the annual meetings, both on the academic and social side. At the Congress itself his many papers showed a genius in the selection and presentation of subjects which would stimulate lively discussion and evoke valuable comment even from many of the more diffident and less vocal members. On the social side his confiding friendliness and infectious good humour made him a centre of affection and amusement, which added so much to that happy family atmosphere which has always been such a delightful feature at Oxford.

Our sympathy goes out to his wife, to whose devotion and help he owed so much and to his family. May those great qualitieswhich endeared him to so many of his colleagues be an abiding memory and consolation to them all.

\section{JOHN LOCKHART GIBSON}

THE death of Mr. Lockhart Gibson on September 30, 1944 was noted in our December issue. We are now able to give some details of his career, thanks to the courtesy of his son Dr. Walter Lockhart Gibson, who has'sent us a copy of the notice in the Medical Journal of Australia. Our facts are taken from this source with acknowledgements to the editor.

John Lockhàrt Gibson, who had been our Brisbane correspondent since our start in 1917; was of Scottish extraction' and born at Ipswich, Queensland in 1860. His education was at the Ipswich Grammar School and his medical training was frorn Edinburgh. He had a brilliant academic career in Edinburgh and deputised for Professor Rutherford in giving the lectures in physiology when the 